\title{
Financial Frictions, Internal Capital Markets, and the Organization of Production*
}

\author{
Pavel Ševčík ${ }^{\dagger}$
}

December 2008

\begin{abstract}
Diversified business groups and conglomerate firms account for a large fraction of corporate assets and business activity in many emerging and developed countries. This paper examines whether a model in which business groups partially substitute for imperfect credit market is able to quantitatively explain key stylized facts on the way production is organized, on cross-firm productivity differences, and on cross-country differences in the degree of conglomeration.
\end{abstract}

${ }^{*}$ I am very grateful to Rui Castro and Alessandro Riboni for their guidance. I would like to thank Wouter Den Haan, Bariş Kaymak, Igor Livshits, Erwan Quintin, Francisco Ruge-Murcia and participants of the Brown Bag Macroeconomic Seminar at Université de Montréal for their comments. All erros are mine.

†Address: Département de Sciences Economiques, Université de Montréal, C.P. 6128, succursale Centre-ville, Montreal, Quebec, H3C 3J7, Canada. E-mail: pavel.sevcik@umontreal.ca. Web: www.sceco.umontreal.ca/phd/sevcik. 


\section{Introduction}

Conglomerates (firms under common ownership that operate in multiple industries) and business groups (groups of legally independent firms that are linked together by strong equity or family ties) account for a large fraction of corporate assets and business activity in many countries. For example, Classens, Djankov, and Lang (2000) find that in five East Asian countries (Hong Kong, Indonesia, South Korea, The Philippines, and Thailand) the largest 15 business family groups control over $30 \%$ of listed corporate assets. Conglomerates and business groups are, in general, more important in East Asia compared to Europe and the United States. However, several empirical studies indicate that they are important in the latter countries as well. For example, in a study on European countries Faccio and Lang (2002) document that the top 15 family groups control more than $30 \%$ of listed corporate assets in Belgium, France, Portugal, and Switzerland. In the US conglomerates are not numerous, but they tend to be very large. Using detailed plant-level data, Maksimovic and Phillips (2002) find that $12 \%$ of firms in US manufacturing industries were conglomerates and that they accounted for around $75 \%$ of the total value of shipments in the $1980 \mathrm{~s}$.

Given the economic weight of these diversified entities, it is important to understand their role and implications for aggregate macroeconomic variables. Why does business conglomeration emerge? Why are diversified groups predominant in some countries and not in others? What are the consequences of business groups for resource allocation? What is the impact on the wealth distribution? Further, understanding conglomerates should also be key for understanding phenomena such as the cross-firm allocation of inputs and production outcomes, the aggregate share of entrepreneurship, or the average productivity of firms.

In order to address these questions I examine the view that business groups substitute for missing or imperfect markets, and assess whether it is consistent with stylized facts on cross-country differences in the presence of business groups, and on the organization of production. More specifically, I develop a model in which conglomeration allows firms to partially avoid external credit market imperfections, and evaluate its capacity to generate quantitative implications that are consistent with the empirical evidence. My model embeds business group 
formation into an otherwise standard heterogeneous agent model of entrepreneurship. Agents of differing abilities and wealth decide whether to be workers or become entrepreneurs. Entrepreneurs choose whether to operate a stand-alone (single-segment) business firm, or to become part of a diversified business group (conglomerate). Because of credit market frictions, only wealthier individuals have full access to external finance. Business groups emerge endogenously as a way for firms to create an internal credit market, reducing their reliance on external funds. Internal capital markets also allow entrepreneurs to reallocate the available capital across group firms more efficiently.

I calibrate the model to match some key observations regarding the importance of entrepreneurship, and overall wealth and earnings inequality. The model performs relatively well in reproducing some of the salient features of the crosssectional distribution of production size. Particularly, through internal reallocation of capital, conglomeration can generate concentration of the affiliated projects in large size categories. The model is also able to reconcile a seemingly contradictory finding in empirical corporate finance literature that plants in conglomerates tend to be on average more productive than those in stand-alone firms (Schoar, 2002), but this relation is inversed if we control for production size (Maksimovic and Phillips, 2002). The model shows that highly productive plants are more likely to select into conglomerates, hence the positive unconditional relation between conglomeration and productivity. On the other hand, because conglomeration relaxes credit constraints, a mass of highly productive plants that are constrained to operate on any given sub-optimal size is lower among conglomerates than among stand-alone firms. Therefore, conditional on most production sizes, except very high ones, the average productivity of plants in conglomerates is lower than in stand-alone firms.

In quantitative experiments I show that more severe credit market frictions lead to a higher degree of conglomeration in the economy. The reason is that internal markets are more profitable in environments with higher frictions in the external markets. Varying the credit frictions can generate differences in the presence of business groups that are broadly consistent with the cross-country empirical evidence. Another experiment studies the effects of conglomeration on economic development. Conglomeration leads to better allocation of capital 
but also, via general equilibrium effects, makes external finance and labor more expensive. My simulations suggest that the direct positive effect dominates and, compared to a model without business groups, conglomeration results in higher levels of capital accumulation, entrepreneurship, and ouput per capita.

\section{$1.1 \quad$ Related Literature}

Business groups, conglomerates, and corporate diversification have received some attention in the corporate finance literature. Existing theoretical papers provide essentially three different explanaitions for business conglomeration. First, several papers (Rajan, Servaes, and Zingales, 2000, Scharfstein and Stein, 2000, Almeida and Wolfenzon, 2006b) argue that business groups emerge as a way to enhance control rights of group insiders and to expropriate outside investors. In these studies conglomeration creates additional layers of agency problems between the headquarters and divisional managers that lead to divisional rent-seeking and inefficient investment. Other papers (Maksimovic and Phillips, 2002, Gomes and Livdan, 2004) view diversification as an optimal response of firms to industry or technological shocks. Here firms diversify to take advantage of economies of scale and to explore new productive opportunities. Finally, a third group of papers argues, like my paper, that business groups arise as a way to substitute for missing or imperfect external markets. According to these studies conglomeration creates an internal market that allocates efficiently ressources accross diversified divisions (Stein, 1997, Almeida and Wolfenzon, 2006). Discrimination between the alternative theories is difficult since the stylized theoretical models cannot be easily taken to the data. The empirical papers, on the other hand, focus on differences in the market valuation of conglomerates and stand-alone firms (Lang and Stulz, 1994, Khanna and Palepu, 2000, Schoar, 2002, Villalonga, 2004, Santalo and Becerra, 2008) but are silent about the underlying mechanisms that lead to business conglomeration.

A rare exception that tries to close the gap between the theoretical and the empirical literature is Gomes and Livdan (2004). They construct a model of corporate diversification that is suitable for calibration and show that a theory in which firms diversify to explore new productive opportunities generates some 
implications that are quantitatively consistent with the empirical evidence. My paper follows this quantitative approach but it differs from Gomes and Livdan (2004) in at least three important aspects. First, I examine a different theory of conglomeration in which credit market frictions play a crucial role. In my model businesses conglomerate to create internal capital markets and avoid frictions on the external credit market through internal reallocation of capital. This idea was first proposed by Stein (1997) and my paper puts it into a full-fledged dynamic general equilibrium model. Second, in Gomes and Livdan (2004) "diversification" means that a single firm (entrepreneur) simply initiates a new technology, whereas in my paper "conglomeration" means that several previously stand-alone firms (entrepreneurs) create a new entity, which pools their technologies and their internal finance. This is particularly important in presence of credit constraints because when raising external finance as a group the net worth of rich and less productive entrepreneurs may be used to collateralize credit for more productive affiliated projects. While their approach corresponds to a particular form of diversification by building a new project "on the green field", mine can be thought of as diversification by acquisition or merger. ${ }^{1}$ Looking at US diversified companies we can find ample examples of diversifiction of both types, and we should think of the two modelling approaches as complementary. ${ }^{2}$ Third, I introduce the occupational choice decision into the model. This links endogenously the share of entrepreneurship, business conglomeration, and credit market imperfections and allows me to explore the implications of business groups from a more macroeconomic perspective.

My paper is also close to Almeida and Wolfenzon (2006), who discuss the implications of conglomeration for the economy-wide efficiency of capital allocation

\footnotetext{
${ }^{1}$ Although in the model I cannot clearly identify an acquirer and a seller, at the end each party receives a remuneration for its project's technology as well as for its net worth. In this way one can think of group formation as one party "purchasing" an ongoing project of the other party including the other party's assets for a price that is bargained between the parties.

${ }^{2}$ The empirical study of Hubbard and Palia (1999) shows that the acquisition-merger view is particularly relevant for the 1960s conglomerate merger wave in the US, and it may also be more suitable for diversified business groups in emerging markets. Japanese keiretsus, Korean chaebols as well as Indian industrial business groups tend to be collections of firms each with its own separate net worth and management. For more detailed description of business groups in these countries see Hoshi, Kashyap, and Scharfstein (1991), Shin and Park (1999), and Khanna and Palepu (2000).
} 
in an evironment with capital market frictions. They argue that business groups improve aggregate capital allocation and lead to a higher equilibrium level of aggregate output when external capital market frictions are severe, but, because of general equilibrium effects, worsen the aggregate capital allocation and lead to a lower aggregate output when capital market frictions are moderate. However, their three-period model is very stylized and does not allow any quantitative conclusions. I revisit their question and find that the negative general equilibrium effects tend to be quantitatively small and endogenous conglomeration leads to higher steady state levels of entrepreneurship, aggregate capital, and aggregate output for realistic parametrizations of my model.

\section{Empirical Evidence}

This section summarizes several stylized facts found in the empirical literature against which my model will be evaluated. These stylized facts come essentially from two types of empirical studies. First, studies on US conglomerates using high-quality plant-level data provide evidence on relative production size and productivity of firms. Second, studies from other countries provide evidence on cross-country differences in the importance of business groups and its link to financial development. Unfortunately, the latter studies are constrained to use substantially lower-quality and coarser firm-level data.

\subsection{Evidence from the US}

\subsubsection{Distribution of Production Size}

The facts on the distribution of relative production size are taken from Maksimovic and Phillips (2002). They use detailed plant-level data on manufacturing sector producers contained in the Longitudinal Research Database (LRD) maintained by the US Bureau of Census. The unit of analysis is a firm-segment. A firm-segment is constructed by aggregating the firm's plant-level data at the three-digit SIC code, therefore representing a firm's operations in a given industry. In their analysis Maksimovic and Phillips (2002) exclude all firm-segments with a value of shipments lower than one million of real dollars. Firms are then classified 
Table I - Distribution of Relative Production Size

\begin{tabular}{|c|c|c|c|}
\hline & Conglomerate & Stand-alone & All \\
\hline \multicolumn{4}{|l|}{ Firm-segment-level Statistics ${ }^{a}$ : } \\
\hline Relative Size & \multicolumn{3}{|c|}{ Fraction of firm-segments } \\
\hline$<0.5$ & $3.1 \%$ & $29.8 \%$ & $18.3 \%$ \\
\hline $0.5-1.0$ & $6.2 \%$ & $30.0 \%$ & $19.7 \%$ \\
\hline $1.0-2.0$ & $8.4 \%$ & $20.4 \%$ & $15.2 \%$ \\
\hline $2.0-5.0$ & $15.4 \%$ & $12.1 \%$ & $13.5 \%$ \\
\hline$>5.0$ & $66.9 \%$ & $7.7 \%$ & $33.3 \%$ \\
\hline Number of firm-segments & 13817 & 18122 & 31939 \\
\hline Proportion of firm-segments & $43.3 \%$ & $56.7 \%$ & $100 \%$ \\
\hline \multicolumn{4}{|l|}{ Firm-level Statistics ${ }^{b}:$} \\
\hline Number of firms & 2143 & 15309 & 17452 \\
\hline Proportion of firms & $12.2 \%$ & $87.8 \%$ & $100 \%$ \\
\hline Proportion of value of shipments & $75.8 \%$ & $24.2 \%$ & $100 \%$ \\
\hline
\end{tabular}

All statistics are computed from Maksimovic and Phillips (1998), and Maksimovic and Phillips (2002). ${ }^{a}$ Statistics on the firm-segment level are averages over the periods 19761978, 1981-1982, 1984-1988 and 1990-1991. ${ }^{b}$ For the firm-level statistics the information is available only at the beginning of the decade (year 1980) and the end of the decade (year 1990). The numbers reported are averages over these two years. Therefore, they need not directly correspond with the firm-segment-level statistics above.

Relative Size is firm-segment's value of shipments divided by industry median value of shipments. Proportion of firm-segments is the percentage of firm-segments of each type in the total number of firm-segments in the sample (a stand-alone firm counts as one firm-segment). Proportion of firms is the percentage of firms of each type in the total number of firms in the sample. Proportion of value of shipments is the percentage of value of shipments of firms of each type in the total value of shipments in the sample.

as single-segment or multiple-segment. A firm is classified as multiple-segment (conglomerate) if it produces more than ten percent of its sales outside its main three-digit SIC code. The relative production size of a firm-segment is measured by the ratio of the firm-segment's total value of shipments to the industry median value of shipments.

Table I reveals several interesting facts about the distribution of relative production size of firm-segments. First, the proportion of conglomerate firm- 
segments is around 43 percent, a number much higher than the proportion of conglomerate firms, which is around 12 percent. This, together with the fact that conglomerates account for around 75 percent of the total value of shipments, points to the importance of multi-segment firms despite their relatively low number. ${ }^{3}$ Second, conglomerate firm-segments tend to be much larger than stand-alone firms. The size distribution is highly skewed towards large size firmsegments for the conglomerates, but it is skewed towards rather small size firmsegments for the stand-alone firms. Unfortunately, from the available information, I am unable to distinguish whether the firm-segment size differences come from the extensive margin (more plants) or the intensive margin (larger plants). Third, the relative importance of the conglomerate firm-segments results into an unconditional distribution that is bi-modal, with one mode of large segments and another mode comprising much of the small stand-alone firms.

\subsubsection{Differences in Total Factor Productivity}

Two recent papers study empirically the productivity differences between conglomerates and stand-alone firms using LRD data. On the plant level, Schoar (2002) reports that plants in stand-alone firms have on average lower total factor productivity (TFP) than plants in conglomerates. This fact contrasts with the findings of Maksimovic and Phillips (2002), who study firm-segment-level TFP. They find that, conditional on size, firm-segments in stand-alone firms are on average more productive than those in conglomerates, except for the lowest size class. Although the two studies use slightly different methodologies and a different unit of observation, ${ }^{4}$ it may seem surprising that they find qualitatively different results. My model will provide a way to reconcile both findings, however, the detailed discussion is postponed to Section 6 .

Maksimovic and Phillips (2002) also show that inside conglomerates more

\footnotetext{
${ }^{3}$ Maksimovic and Phillips (2002) report that the proportion of conglomerate firm-segments ranges, depending on the time period, between 31 and 53 percent and it tends to be higher in expansion years and lower in recession years. In the present paper, I abstract from business cycle dynamics and focus on long term implications. For that purpose the average of 43 percent over all periods seems to be a reasonable number.

${ }^{4}$ In Schoar (2002) the unit of observation is a plant, whereas in Maksimovic and Phillips (2002) it is a firm-segment.
} 
productive segments are of larger production size. This is consistent with efficient resource allocation within conglomerates.

\subsection{Evidence from Other Countries}

\subsubsection{Sensitivity of Investment to Internal Finance}

The investment of the firms affiliated with business groups is less sensitive to the firm's internal funds than the investment of stand-alone firms. This stylized fact is documented by Hoshi, Kashyap and Scharfstein (1991) for the firms affiliated with Japanese keiretsu groups, by Shin and Park (1999) for the Korean conglomerates - chaebols, and by Perotti and Gelfer (2001) for the Russian financial-industrial groups. This has been interpreted as supporting evidence for the existence of financial constrains, and for the fact that business groups can help the affiliated firms to overcome these constraints. This interpretation will be consistent with my model.

\subsubsection{Presence of Business Groups and Investor Protection}

If business groups are a way to address external capital market imperfections, they should be prevalent in environments where these imperfections are high. One way to measure these imperfections is to look at indicators of investor protection. Figure I plots the proportion of group-affiliated firms and effective investor protection index in a cross-section of countries. The data on group affiliation are from Khanna and Yafeh (2005). It should be kept in mind that the authors use several country-specific definitions of group affiliation since it is hard to find a unique definition that can be applied in different countries. The effective investor protection index is constructed by multiplying the sum of the shareholder protection index and creditors' right index (La Porta et al., 1998) by the rule

of law index (Kaufmann, Kray, and Mastruzzi, 2006). Although the number of data points is limited, the figure suggests that groups tend to be more present in the countries with lower investor protection; the negative relation is statistically significant at the ten percent level. 


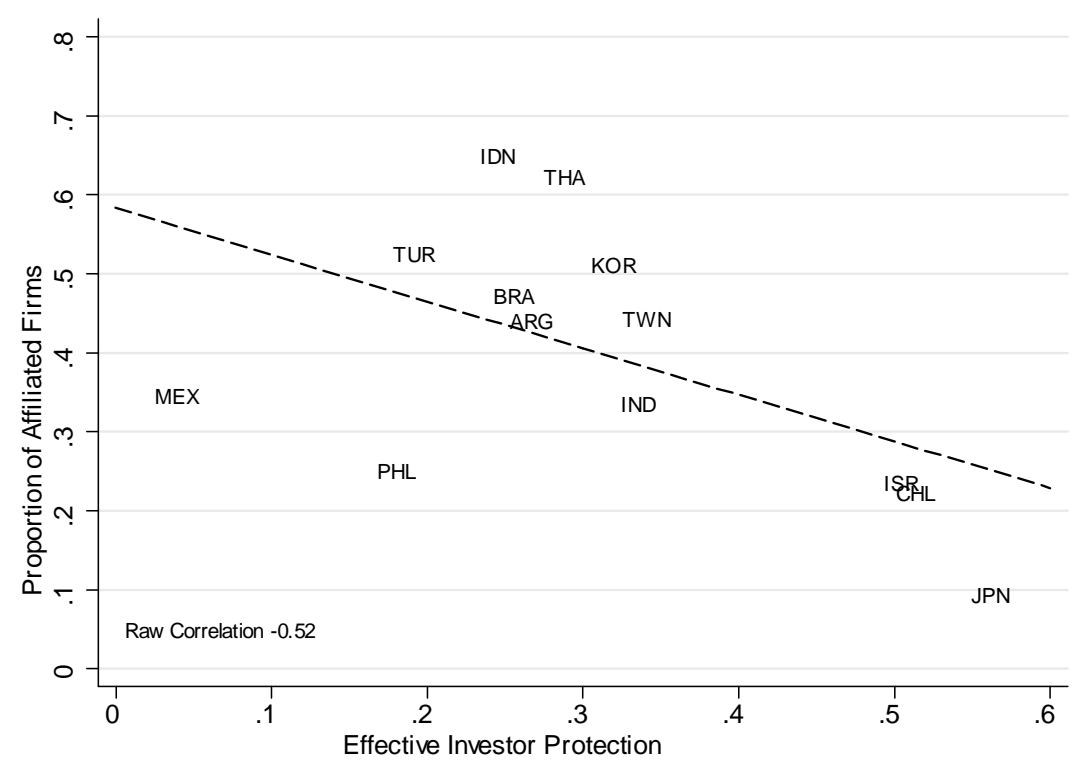

Figure I - Conglomeration and Investor Protection

\subsubsection{Development, Entrepreneurship, and Size of Establishments}

Tybout (2000), and Gollin (2008) show evidence that in less developed countries more people are entrepreneurs, and that they manage firms of a smaller size than in the developed countries. That is, the number of establishments is inversly related to the economic development, whereas the size of these establishments is positively related to the economic development. Simple models of entrepreneurship such as Cagetti and De Nardi (2006) fail to generate this stylized fact. Particularly, they imply entrepreneurship to be increasing with the level of financial and economic development. While there are other papers that concentrate on this issue (see Gollin (2008) for a model specifically designed to account for self-employment), my model's implications are consistent with the stylized fact.

\subsection{Summary of Evidence}

For conveniece, this section summarizes the evidence presented above.

1. The distribution of relative production size of firm-segments is highly skewed to large sizes in conglomerates. It is skewed to small sizes in stand-alone 
(single-segment) firms. Unconditional on firm type, the distribution of relative production size of firm-segments is bi-modal with concentration of mass in both tails.

2. Unconditionaly on plant size, plants in stand-alone firms have lower TFP than plants in conglomerates. Conditionaly on firm-segment size, firmsegments in stand-alone firms have higher TFP than firm-segments in conglomerates.

3. The investment of the firms affiliated with business groups is less sensitive to the firm's internal funds than the investment of stand-alone firms.

4. The degree of conglomeration seems to be on average higher in countries with lower investor protection.

5. The number of establishments is inversly related to the economic development, whereas the size of these establishments is positively related to the economic development.

\section{The Model}

The economy is populated with a continuum of measure one of infinitely-lived risk-averse agents. The consumption streams are valued according to

$$
U\left(\left\{c_{t}\right\}_{t=0}^{\infty}\right)=E_{0} \sum_{t=0}^{\infty} \beta^{t} u\left(c_{t}\right),
$$

where the period utility function $u(c)$ is strictly increasing, strictly concave and satisfies the usual Inada conditions. Every period each agent is endowed with one unit of time that he can either supply on the labor market or use to manage his own entrepreneurial project. Leisure is not valued. The return to each occupational activity depends on the agent's working or managerial talent. The working and managerial abilities are denoted by $\zeta$ and $\theta$, respectively, and their logarithms are assumed to follow exogenous $\mathrm{AR}(1)$ processes that are uncorrelated with each 
other. ${ }^{5}$ In each period the agents choose whether they will work for a wage or become entrepreneurs after observing their individual ability shocks.

Production is carried out by entrepreneurs. As in Lucas (1978), an entrepreneurial project necessitates three inputs in order to be productive: entrepreneurmanagerial time, capital $k$, and labor $l$. Entrepreneur $i$ combines these inputs according to a decreasing returns to scale technology $y_{i t}=\theta_{i t}\left(k_{i t}^{\alpha} l_{i t}^{1-\alpha}\right)^{\nu}$, where $\theta_{i t}$ is the managerial ability. The share parameters $\alpha$ and $\nu$ have values between zero and one. $(1-\nu)$ can be interpreted as the span of control of the entrepreneur-manager. During production, capital depreciates at rate $\delta$.

The sole asset in the economy is productive capital. Consumers can save by accumulating capital, which is then lent to the entrepreneurs at the interest rate $r$. Borrowing to finance consumption is not allowed. ${ }^{6}$ Contracts between entrepreneurs and lenders suffer from imperfect enforceability, which limits the external financing of entrepreneurial projects. Specifically, I assume that lender repayment can be enforced only up to a fraction $\eta$ of entrepreneur's net worth $a$.

Besides accessing external funds in the credit market, entrepreneurs have the option to create internal capital markets by forming business groups. A business group allows the affiliated entrepreneurs to allocate capital among their projects internally, without being subject to enforcement problems. For simplicity, and to keep the model computationally manageable, I consider business groups with only two members. The creation of business groups occurs in the following fashion. After the occupational choice decision the agents who have chosen to become entrepreneurs meet randomly in pairs and observe each other's managerial abilities and net worth. If two agents $i$ and $j$ meet, they may form a business group. A business group consists of a headquarters and the projects of the affiliated entrepreneurs. Headquarters pools the internal assets of the partners and, eventually, raises additional funds on the external credit market. Then it reallocates the total available capital between the affiliated projects as to maximize the group profit, avoiding any enforcement frictions. ${ }^{7}$ I assume that conglomeration entails

\footnotetext{
${ }^{5}$ I have also computed a version of the model with positive correlation between the ability processes. The results stay qualitatively unchanged.

${ }^{6}$ Huggett (1997) makes a similar set of assumptions.

${ }^{7}$ The assumption is that the headquarters has the power to reallocate the total capital available as opposed to only its part that has been raised on the external market. In this aspect
} 
a fixed cost $\gamma$. This reflects two things: first it is more costly to manage a business group because of a complicated organizational structure. The simplest interpretation is to say that there is a cost of creating and operating the headquarters. Eventually, there may arise additional agency problems between the headquarters and project managers (Rajan, Servaes, and Zingales, 2000, Scharfstein and Stein, 2000, and others). Although I do not model these agency problems explicitely, $\gamma$ can be thought of as a reduced form of the cost implied by these additional agency problems. Yet another interpretation that may be advanced is the cost of reallocating capital that is already installed in each project. Second, imposing a cost of conglomeration may also be motivated by policy-related issues. For example, it may be costly to establish a business group due to regulation of mergers, anti-trust laws, and policies imposing restrictions on the size of large firms.

I assume that the group profit is shared by the affiliated entrepreneurs according to the Shapley value solution. Thus, each partner is rewarded according to his contribution to the creation of group profits. Particularly, capital provision and managerial talent (or technology) provision are both accounted for in the remuneration. In this aspect a business group acts as an internal capital market, but it also acts as an imperfect substitute for market for ideas and entrepreneurial assets.

The timing of events within each period is given by the following sequence.

1. Individual exogenous states $\left(\zeta_{i}, \theta_{i}\right)$ of each agent are realized.

2. Agents choose their occupation. They cannot change the occupation in the subsequent stages of the current period.

3. Entrepreneurs meet in pairs and observe their managerial abilities and net worth. They choose whether to form a business group or not. Conglomeration necessitates consent of both partners. At the end of this stage some entrepreneurs will be conglomerated in a group while others will run stand-alone projects.

the headquarters engages in the "winner picking and loser sticking". By forming a business group the entrepreneurs agree to pass the control over their internal assets to the headquarters. 
4. Entrepreneurs and business groups search external finance on the capital market. Inside business groups the capital is allocated to the projects so as to maximize the group profit.

5. Production takes place, wages and interests are paid, external capital is returned to the lenders, profits are realized. In business groups the group profit is divided between the partners according to the Shapley value rule.

6. Agents choose how much to save for future periods.

There are two assumptions in the timing that need to be discussed. First, the assumption of within-period-irreversible occupational choice before business group formation takes place. This ensures that only the agents who have already engaged their net worth in entrepreneurship may affiliate business groups. This seems realistic, in order to aspire to merge with a strategic partner it is important that a project already has a label of an active business. ${ }^{8}$ Second, I assume that business groups are dissolved at the end of each period and formed anew the next period. This is a strong assumption. In reality, business group affiliation is rather persistent. In my model, the high persistence of the managerial ability shocks ensures that certain types of entrepreneurs tend to nearly always participate in a business group. However, their business partners are constantly changing. The assumption is necessary to maintain the complexity of the model manageable. Were groups allowed to operate for several periods, both group formation (or dissolution) and the saving decisions of the parners would be the solution of a complex dynamic game. The dynamic strategic interactions would arise since each partner's decision rules would have to be a best response to the other partner's decision rules, together with the outside option of staying alone and searching for a new partner in the next period. While these matters are certainly interesting, they are very hard to deal with in a general equilibrium framework and are thus out of the scope of this paper.

\footnotetext{
${ }^{8}$ I have also solved the model with a modified timing in which the occupational choice occurs at the same time as group formation. That allows any agent (as opposed to only commited entrepreneurs) to enter into business groups. Results from that version are qualitatively similar, but the model is less successful from a quantitative perspective.
} 


\section{Competitive Equilibrium}

In this section I define the competitive equilibrium. I start with the consumptionsaving problem and proceed to the occupational choice decision. Finally, I define the profit maximization problems of stand-alone firms and business groups.

In the maximization problems bellow, the joint distribution over the individual states $\Psi$ is an aggregate state variable and in principle the agents need to know its law of motion in order to predict future prices and eventual business partner's type. However, in this paper I am going to focus on the stationary equilibria in which prices are constant and the distribution over individual states is invariant. All maximization problems can thus be written as being parametrized in the prices and the stationary distribution $\Psi$. To increase readability, I do not include $r, w$, and $\Psi$ in the arguments of value functions in what follows.

\subsection{Consumption-saving Decision}

At the end of the period agents decide how much to save. Let $V\left(\zeta_{i}, \theta_{i}, \omega_{i}\right)$ denote the end-of-period value function of an agent with abilities $\zeta_{i}, \theta_{i}$ and end-of-period assets $\omega_{i}$. Let also $W\left(\zeta_{i}, \theta_{i}, a_{i}\right)$ denote the value function at the beginning of period of an agent who observed his abilities $\zeta_{i}, \theta_{i}$ and who has saved $a_{i}$ from the last period. The value function $W\left(\zeta_{i}, \theta_{i}, a_{i}\right)$ already includes the occupational choice decision, which will be described in detail in the next section. The saving decision of agent $i$ is then given by the following Bellman equation:

$$
V\left(\zeta_{i}, \theta_{i}, \omega\right)=\max _{a_{i}^{\prime} \geq 0}\left\{u\left(\omega_{i}-a_{i}^{\prime}\right)+\beta E_{\zeta_{i}^{\prime}, \theta_{i}^{\prime}}, W\left(\zeta_{i}^{\prime}, \theta_{i}^{\prime}, a_{i}^{\prime}\right)\right\}
$$

\subsection{Occupational Choice}

At the beginning of the period, but after observing his working and managerial abilities, the agent can either become a worker and invest his net worth $a_{i}$ in the credit market, which will yield at the end of the period assets

$$
\omega_{i}^{W} \equiv \zeta_{i} w+(1+r) a_{i}
$$


or he can choose to become an entrepreneur and use $a_{i}$ to finance his business activity. In this case the amount of assets that will be generated at the end of the period depends on whether the entrepreneur affiliates to a business group or not. Let $Z^{S A}\left(\theta_{i}, a_{i}\right)$ be the indirect profit function when entrepreneur $i$ operates as a stand-alone firm, and $Z_{i}^{G}\left(\theta_{i}, a_{i}, \theta_{j}, a_{j}\right)$ the function that gives entrepreneur $i$ 's share of the group profit when $i$ and $j$ form a business group. These indirect profit functions come from static profit maximization problems that are described in the next section. The end-of-period assets of entrepreneur $i$ can be written as

$$
\omega_{i j}^{E} \equiv \max \left\{Z^{S A}\left(\theta_{i}, a_{i}\right), Z_{i}^{G}\left(\theta_{i}, a_{i}, \theta_{j}, a_{j}\right)\right\}+(1+r) a_{i} .
$$

However, at the moment of deciding his occupation the agent does not know his potential business partner and has to make a conjecture on the partner's type. The expectation is taken over the set of entrepreneurs $B$ with respect to the invariant measure $\Psi$. The occupational choice is then given by

$$
W\left(\zeta_{i}, \theta_{i}, a_{i}\right)=\max \left\{V\left(\zeta_{i}, \theta_{i}, \omega_{i}^{W}\right), E_{\left(\zeta_{j}, \theta_{j}, a_{j}\right) \in B} V\left(\zeta_{i}, \theta_{i}, \omega_{i j}^{E}\right)\right\}
$$

Notice that due to the max operator, the value function $W\left(\zeta_{i}, \theta_{i}, a_{i}\right)$ need not be concave in the net worth $a_{i}$ even if the value of working and the expected value of entrepreneurship are concave in $\omega .{ }^{9}$ Compared to a standard occupational choice problem without business groups, the value of entering into entrepreneurship becomes a stochastic variable depending on the random match with a partner. Agents consider the possibility of obtaining higher profits in a conglomerate if they meet a suitable partner, but also the possibility that their profits may be lower if they are credit constrained and have to operate their project as a stand-alone firm if the match is bad.

\subsection{Profits and Factor Demands}

Given prices, stand-alone firms and business groups decide how much of labor and capital they will contract to maximize their profits. Business groups also

\footnotetext{
${ }^{9}$ Dynamic models of occupational choice often feature such a non-convexity, see for example Gomes, Greenwood, and Rebelo (2001), Bohacek (2006), Vershchagina and Hopenhayn (2006).
} 
decide how to allocate capital to the affiliated projects. Entrepreneur $i$ who meets entrepreneur $j$ contracts $l\left(\theta_{i}, a_{i}, \theta_{j}, a_{j}\right)$ units of labor and $k\left(\theta_{i}, a_{i}, \theta_{j}, a_{j}\right)$ units of capital. These factor demands are the solution of profit maximization either for a stand-alone firm of entrepreneur $i$, or for a business group $\{i, j\}$. The profit maximization problems are static.

\subsubsection{Stand-alone Entrepreneurs}

A stand-alone project generates net profits according to:

$$
Z^{S A}\left(\theta_{i}, a_{i}\right)=\max _{k_{i}, l_{i}}\left\{\theta_{i}\left(k_{i}^{\alpha} l_{i}^{1-\alpha}\right)^{\nu}-(r+\delta) k_{i}-w l_{i}\right\}
$$

subject to

$$
(1+r)\left(k_{i}-a_{i}\right) \leq \eta a_{i}
$$

The borrowing constraint says that the repayment must be lower than a fraction $\eta$ of the entrepreneur's net worth. The parameter $\eta$ determines the tightness of the borrowing constraint. When $\eta$ is low some entrepreneurs are constrained to implement their project in a sub-optimal size. The dependence of the credit contracts on the entrepreneurial net worth prevents the external capital to be allocated optimally among all productive projects.

\subsubsection{Business Groups}

In this paper I focus on the role of internal capital markets inside the business groups. To analyse the working of these internal markets as clearly as possible, I assume away economies of scale and ability spill-overs or other externalities created through joint group management. Each project is still attached to a particular entrepreneur-manager, only capital may be reallocated among the affiliated projects. A business group that disposes with managerial abilities $\theta_{i}$ and $\theta_{j}$ and total net worth $a$ generates net profits according to:

$$
\begin{array}{r}
Z^{G}\left(\theta_{i}, \theta_{j}, a\right)=\max _{k_{i}, l_{i} k_{j}, l_{j}}\left\{\theta_{i}\left(k_{i}^{\alpha} l_{i}^{1-\alpha}\right)^{\nu}+\theta_{j}\left(k_{j}^{\alpha} l_{j}^{1-\alpha}\right)^{\nu}-\gamma\right. \\
\left.-(r+\delta)\left(k_{i}+k_{j}\right)-w\left(l_{i}+l_{j}\right)\right\}
\end{array}
$$


subject to

$$
(1+r)\left(k_{i}+k_{j}-a\right) \leq \eta a
$$

$\gamma$ is the (fixed) cost of conglomeration. A business group acts as a single entity when going to the external capital market and the credit constraint applies on the group level (total of external funds raised that depends on the total of internal finance available) and not on the each affiliated project level.

Group profit is shared according to the Shapley value solution. Each partner is paid the averge of his marginal contributions to the creation of group profit. ${ }^{10}$ Partner $i$ obtains

$$
Z_{i}^{G}\left(\theta_{i}, a_{i}, \theta_{j}, a_{j}\right)=\frac{1}{2}\left[Z^{G}\left(\theta_{i}, \theta_{j}, a_{i}+a_{j}\right)-Z^{S A}\left(\theta_{j}, a_{j}\right)+Z^{S A}\left(\theta_{i}, a_{i}\right)\right] .
$$

A business group is feasible if the profit that each partner could obtain as a stand-alone entrepreneur is lower than his remuneration from the business group. This is guaranteed whenever

$$
Z^{G}\left(\theta_{i}, \theta_{j}, a_{i}+a_{j}\right) \geq Z^{S A}\left(\theta_{i}, a_{i}\right)+Z^{S A}\left(\theta_{j}, a_{j}\right)
$$

In that case the business group formation is a convex cooperative game and the Shapley value is included in the core of that game.

Notice that because conglomeration is costly, efficiency dictates that there would be no business groups if the credit market was perfect. Without borrowing constraints, the external capital market would ensure equalization of marginal product of capital across stand-alone firms. However, in presence of borrowing constraints the production size of each project is linked to the amount of internal finance that acts as a collateral. Consequently, some very productive projects have to be operated on an sub-optimal scale if the entrepreneur is poor. In this environment, a possibility of forming a business group and reallocating capital internally may generate large gains. Inside the business group the most productive

\footnotetext{
${ }^{10}$ Because I allow only for two-member groups the Shapley value solution is particularly simple and identical to the generalized Nash bargaining solution with equal bargaining powers. I consider the Shapley value since it allows to think of business group formation as a cooperative game with a specific surplus-sharing rule. This interpretation seems to me better suited and more micro-founded.
} 
project receives most of capital and its credit constraint is eased, possibly on expense of tightening it for the less productive project. This corresponds to "winner picking and looser sticking" (Stein, 1997) and leads to more efficient allocation of capital. Of course, it follows that a necessary condition for group formation is that at least one of the affiliated projects would be credit constrained were it operated as a stand-alone firm. The gain from conglomeration rises with the net worth - productivity mismatch of the affiliated entrepreneurs. It is highest when a poor high-productivity type meets a rich low-productivity type.

I now provide a formal definition of the equilibrium.

Definition 1 A stationary equilibrium is an invariant joint distribution of types over the individual states $\Psi$, prices $r$ and $w$, set of entrepreneurs $B$, indirect profit functions $Z^{S A}(\theta, a), Z^{G}\left(\theta_{m}, \theta_{n}, a\right)$, and $Z_{m}^{G}\left(\theta_{m}, a_{m}, \theta_{n}, a_{n}\right)$, and associated allocation functions $k\left(\theta_{m}, a_{m}, \theta_{n}, a_{n}\right), l\left(\theta_{m}, a_{m}, \theta_{n}, a_{n}\right)$ for $m, n \in B$, and value functions $V\left(\zeta_{i}, \theta_{i}, \omega_{i}\right)$ and $W\left(\zeta_{i}, \theta_{i}, a_{i}\right)$ together with the associated saving decision rule $g\left(\zeta_{i}, \theta_{i}, \omega_{i}\right)$ such that:

- Given the distribution $\Psi$, and the prices $r$ and $w$, the indirect profit functions and allocation functions solve (3), (4) and (5).

- Given the distribution $\Psi$, and the prices $r$ and $w$, the value functions and the decision rule solve (1) and (2).

- Given the distribution $\Psi$, and the prices $r$ and $w$, the set of entrepreneurs is $B=\left\{\left(\zeta_{i}, \theta_{i}, a_{i}\right): V\left(\zeta_{i}, \theta_{i}, \omega_{i}^{W}\right) \leq E_{\left(\zeta_{j}, \theta_{j}, a_{j}\right) \in B} V\left(\zeta_{i}, \theta_{i}, \omega_{i j}^{E}\right)\right\}$.

- Labor market clears

$$
\int_{m \in B} \int_{n \in B} l\left(\theta_{m}, a_{m}, \theta_{n}, a_{n}\right) d \Psi d \Psi=\int \zeta_{i} d \Psi-\int_{m \in B} \zeta_{m} d \Psi
$$

- Capital market clears

$$
\int_{m \in B} \int_{n \in B} k\left(\theta_{m}, a_{m}, \theta_{n}, a_{n}\right) d \Psi d \Psi=\int a_{i} d \Psi
$$


- Consumption good market clears

$$
\begin{aligned}
\int\left[\omega_{i}-g\left(\zeta_{i}, \theta_{i}, \omega_{i}\right)\right] d \Psi=\int_{m \in B} y_{m}-\delta k & \left(\theta_{m}, a_{m}, \theta_{n}, a_{n}\right) d \Psi \\
& -\int_{m \in B} \int_{n \in B} \mathbf{1}_{[\{m, n\}]} \frac{\gamma}{2} d \Psi d \Psi,
\end{aligned}
$$

where $\mathbf{1}_{[\{m, n\}]}$ is an indicator function, which equals one if $\{m, n\}$ form a business group and zero otherwise.

- The invariant distribution $\Psi$ is generated by the exogenous ability processes together with the agents decision rules.

\section{Analysis}

\subsection{Occupational Choice}

Given working and managerial abilities, the expected value of each occupation depends on the agent's net worth $a_{i}$. The occupational choice decision can then be characterized by a simple cut-off rule: an agent becomes an entrepreneur if his net worth is higher than a threshold $\bar{a}\left(\zeta_{i}, \theta_{i}\right)$, which is the solution of

$$
V\left(\zeta_{i}, \theta_{i},\left.\omega_{i}^{W}\right|_{a_{i}=\bar{a}\left(\zeta_{i}, \theta_{i}\right)}\right)=E_{\left(\zeta_{j}, \theta_{j}, a_{j}\right) j \in B} V\left(\zeta_{i}, \theta_{i},\left.\omega_{i j}^{E}\right|_{a_{i}=\bar{a}\left(\zeta_{i}, \theta_{i}\right)}\right) .
$$

Figure II illustrates the threshold $\bar{a}\left(\zeta_{i}, \theta_{i}\right)$ for two values of $\zeta_{i}$ and ten values of $\theta_{i} \cdot{ }^{11}$ For some combinations of abilities such a threshold may not exist. Particularly, for some agents, becoming entrepreneur is never profitable enough to guarantee them an expected value of entrepreneurship higher than the value of working for wage. The threshold $\bar{a}\left(\zeta_{i}, \theta_{i}\right)$ is increasing in the working ability $\zeta_{i}$, and decreasing in the managerial ability $\theta_{i}$. This follows directly from monotonicity of $V\left(\zeta_{i}, \theta_{i}, \omega_{i}\right)$ in $\omega_{i}$, which is guaranteed by the assumption of strictly increasing utility function. Intuitively, for any given net worth, higher $\zeta_{i}$ increases the value of working for wage. On the other hand, higher $\theta_{i}$ makes

\footnotetext{
${ }^{11}$ Figure II is constructed using the benchmark calibration that is detailed in Section 6 . Qualitative conclusions are unchanged for alternative calibrations.
} 
entrepreneurship profitable even on smaller scale.

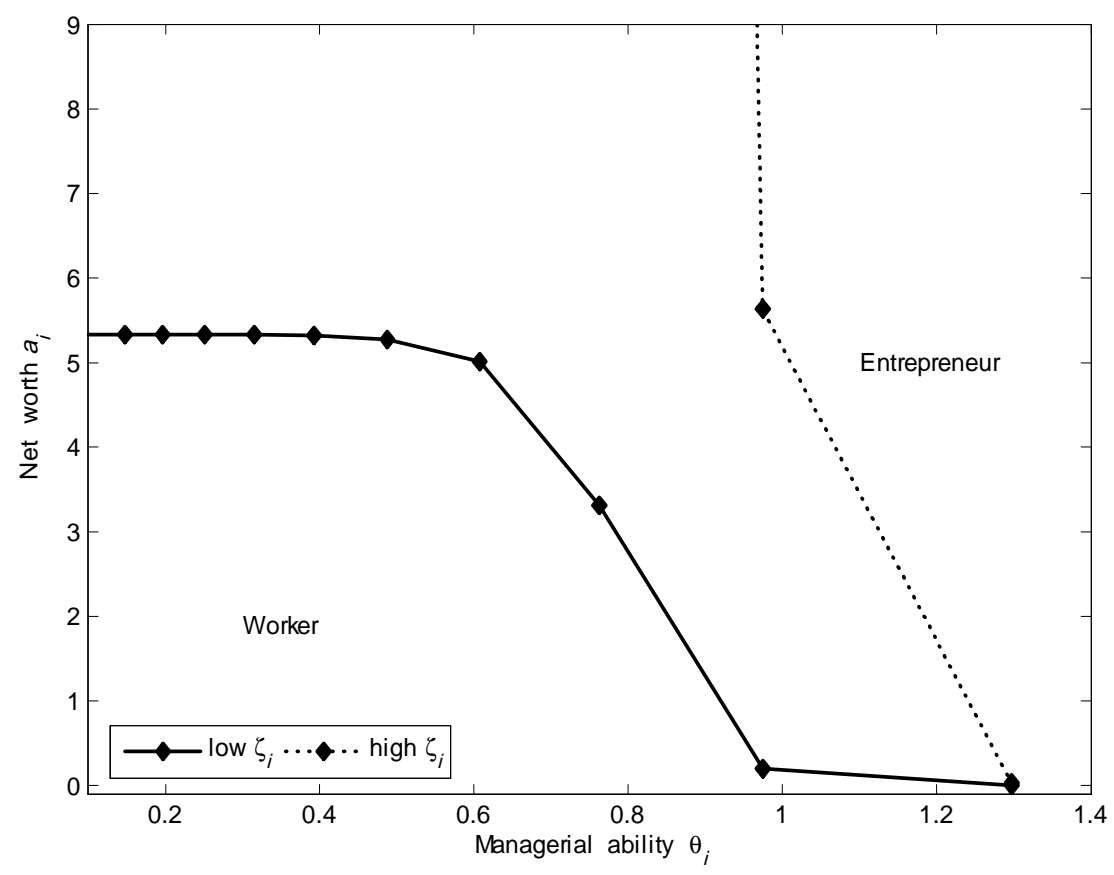

Figure II - Occupational Choice

\subsection{Conglomeration}

To gain more intuition on the selection of entrepreneurs into business groups I would like to represent the conglomeration decision in the space of state variables. Given prices, four individual state variables are relevant for the decision: each partner's managerial ability, $\theta_{i}$ and $\theta_{j}$, and each partner's net worth, $a_{i}$ and $a_{j}$, respectively. Since the gain from conglomeration depends crucially on the net worth-productivity mismatch between the two partners, let us first fix the total amount of net worth available to the group at $a$. Now assume that partner $i$ 's net worth accounts for share $\phi$ of this total net worth, therefore $a_{i}=\phi a$ and $a_{j}=(1-\phi) a$. For a given $\phi$ and $a$, I can plot curves in the $\left(\theta_{i}, \theta_{j}\right)$ space along which the joint group profit equals the sum of profits if the two projects were operated as stand-alone firms. More formally, I draw the set of couples $\left(\theta_{i}, \theta_{j}\right)$ 

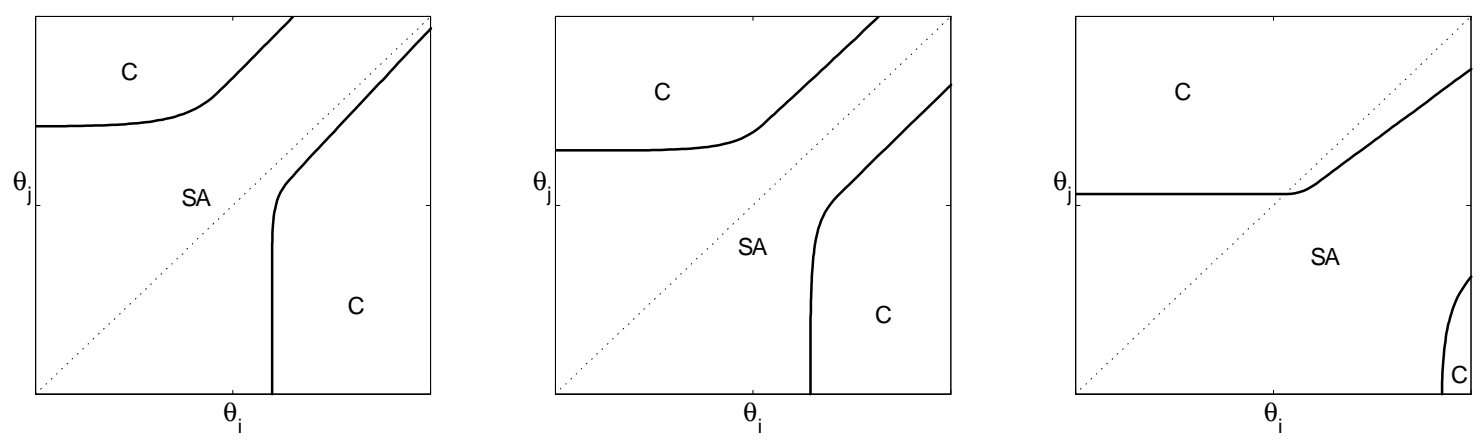

Figure III - Conglomeration Decision, $\phi=0.3, \phi=0.5$, and $\phi=0.9$

satisfying the following equation

$$
Z^{G}\left(\theta_{i}, \theta_{j}, a\right)=Z^{S A}\left(\theta_{i}, \phi a\right)+Z^{S A}\left(\theta_{j},(1-\phi) a\right)
$$

Refer to Figure III. Each panel depicts such curves for $\phi=0.3,0.5$ and 0.9 , respectively, and a 45-degree dotted line. The curves represent matches in which both entrepreneurs are indifferent between operating in a business group or as stand-alone firms. The curves divide the space into three regions. Regions labeled with $\mathrm{C}$ represent the set of matches that lead to conglomeration. The points in the SA region correspond to matches that will be operated as two stand-alone firms. The shape of the curves is related to the fixed cost of conglomeration. Particularly, if both partners have managerial ability lower than some threshold, no internal reallocation will make enough gains to compensate for the fixed cost $\gamma$, and entrepreneurs will operate stand-alone firms.

Now concentrate on the middle panel of the figure. It plots the conglomeration decision when both partners have the same amount of net worth $(\phi=0.5)$. In this case the 45-degree line is never in the $\mathrm{C}$-region. This is intuitive since there are no possible gains from internal capital reallocation if both partners are of exactly the same type. The C-regions are located in the opposing corners, where the parners are heterogeneous enough in managerial abilities. Because capital is reallocated efficiently inside a business group, the more productive entrepreneur will operate his project on a larger scale. From this fact we can identify the internal flows of capital. In the upper left C-region capital is reallocated from en- 
trepreneur $i$ to entrepreneur $j$, and in the lower right C-region capital flows in the opposite direction. This interpretation applies to the other panels of the figure as well. The only difference is that as $\phi$ increases (decreases) the indifference curves shift down (up) and to the right (left). The intuition is that with more net worth inequality among the partners (further $\phi$ is from 0.5), less productivity inequality is necessary to find a profitable reallocation of capital through conglomeration. Eventually, a portion of the 45-degree line will cross one of C-regions as in the right panel $(\phi=0.9)$ in Figure III. The points in the upper left C-region that are below the dotted line are the matches in which a relatively wealthy entrepreneur $i$ conglomerates with a relatively poor entrepreneur $j$, who also has lower managerial ability. However, the conglomeration is profitable, because the difference in marginal products of capital is high enough, and the internal flow of capital goes from $i$ to $j$ so that the marginal products are equalized. In conclusion, matches that lead to conglomeration must feature either high enough differences in managerial abilities of the partners or high enough differences in the partners' net worth. The analysis stays qualitatively the same for different values of the total assets available to the group $a$, only the indifference curves shift closer to each other as $a$ increases.

A direct implication of the efficient internal capital reallocation is that the model is consistent with the stylized fact number three: the investment of the projects in business groups is less sensitive to the entrepreneur's internal finance, because the partner's net worth can make up for the missing collateral.

\section{Calibration}

\subsection{Functional Forms}

For the period utility function I choose the constant elasticity of substitution form

$$
u(c)=\frac{c^{1-\sigma}-1}{1-\sigma} .
$$

Logarithms of the working and managerial abilities are assumed to follow independent exogenous stochastic $\operatorname{AR}(1)$ processes with persistance $\rho_{\zeta}$ and $\rho_{\theta}$, and variance $\sigma_{\zeta}$ and $\sigma_{\theta}$, respectively. I approximate the $\mathrm{AR}(1)$ processes with first 
order Markov chains using two states for the working ability and ten states for the managerial ability. The approximation is computed using the technique of Tauchen and Hussey (1991). The mean of the working ability is normalized to one, whereas the mean of the managerial ability $\mu$ is calibrated jointly with other parameters to match selected moments in the US data.

\subsection{Parametrization}

A set of parameters is calibrated using standard practice in the macroeconomic literature and evidence from independent studies. The inverse of intertemporal elasticity of substitution $\sigma$ is set to 1.5 , the time preference parameter $\beta$ to 0.87 , and capital depreciation $\delta$ to 0.08 in line with the standard practice in the macroeconomic calibration literature. Decreasing returns to scale parameter, $\nu$, is set to 0.88 . This is well within the range of values used by recent studies on entrepreneurship (Burnside, 1996 estimates it to 0.92, Gomes and Livdan, 2004 implicitly use a value of 0.95, Cagetti and De Nardi, 2006 calibrate it to 0.88, Amaral and Quintin, 2007 use 0.85, Gollin, 2008 sets it at 0.9, and Buera and Shin, 2007 calibrate it to 0.82 ). Parameter $\alpha$ is chosen to match the aggregate capital income share by imposing $\alpha \nu=0.33$.

The remaining seven parameters, the persistance and variance of the ability processes $\rho_{\zeta}, \rho_{\theta}, \sigma_{\zeta}$, and $\sigma_{\theta}$, the mean of the managerial ability process $\mu$, the fixed cost of conglomeration $\gamma$, and the credit enforcement parameter $\eta$, are jointly calibrated so that the model approximately matches seven moments in the US data. These moments are: the average Gini coefficient of the workers' earnings in the Panel Study of Income Dynamics (PSID), reported by Cagetti and De Nardi (2006) to be 0.38, the Gini coefficients of the workers' and entrepreneurs' wealth in the PSID of 0.73 and 0.69 as reported by Bohacek (2006), the average exit rate from entrepreneurship of $24.2 \%$ reported by Quadrini (2000), the proportion of entrepreneurs defined as active business owners in the Survey of Consumer Finances of $11.5 \%$ reported by Cagetti and De Nardi (2006), the average proportion of firm-segments affiliated with conglomerates of 0.43 from

Maksimovic and Phillips (2002), and the average fraction of external financing of 0.54 obtained by dividing the sum of credit market liabilities of the private 
sector by the aggregate capital stock of this sector (this moment is taken from Buera and Shin, 2007). Tables II and III summarize the baseline calibration and the moments matched.

Table II - Baseline Calibration

\begin{tabular}{clc}
\hline \hline Parameter & Description & Value \\
\hline$\sigma$ & Inverse of intertemporal elasticity of substitution & 1.5 \\
$\beta$ & Discount rate & 0.87 \\
$\delta$ & Depreciation rate & 0.08 \\
$\nu$ & Variable factors output share & 0.88 \\
$\alpha$ & Capital share in the output to variable factors & 0.378 \\
$\rho_{\zeta}$ & Persistence of the working ability process & 0.98 \\
$\rho_{\theta}$ & Persistence of the managerial ability process & 0.92 \\
$\sigma_{\zeta}$ & Variance of the working ability process & 0.5 \\
$\sigma_{\theta}$ & Variance of the managerial ability process & 0.04 \\
$\mu$ & Mean of the managerial ability process & 0.5 \\
$\gamma$ & Fixed cost of conglomeration & 0.5 \\
$\eta$ & Enforcement of credit contracts & 3.0 \\
\hline \hline
\end{tabular}

Table III - Moments Matched

\begin{tabular}{lll}
\hline \hline Moment & Data & Model \\
\hline Gini workers' earnings & 0.38 & 0.30 \\
Gini workers' wealth & 0.73 & 0.58 \\
Gini entrepreneurs' wealth & 0.69 & 0.51 \\
Exit rate from entrepreneurship & 0.24 & 0.23 \\
Proportion of entrepreneurs & 0.11 & 0.10 \\
Proportion of conglomerate firm-segments & 0.43 & 0.41 \\
Proportion of external financing & 0.54 & 0.52 \\
\hline \hline
\end{tabular}




\section{Results}

\subsection{Production Size Distribution}

In this section I look at the equilibrium distribution of production size that is generated by the model and compare it to the stylized facts on this distribution mentioned in Section 2. The stylized facts are established using the relative production size defined as the value of shipments of a firm-segment divided by the median value of shipments in the firm-segment's industry. Since I do not model explicitely different industries, I define the relative production size in the model as the production of each project divided by the median production in the whole cross-section of active projects.

Table IV shows that the success of the model in reproducing the features of the relative production size distribution is mixed. In line with the data, the model generates concentration of the stand-alone firms in the low size categories and some concentration of the conglomerated firm-segments in the large size categories. The main discrepancy between the data and the model is that the model generates too much firm-segments in the lowest relative size category. This problem is particularly severe for the conglomerated firm-segments.

Table IV - Distribution of Relative Production Size

\begin{tabular}{ccccccccc}
\hline \hline & \multicolumn{2}{c}{ Conglomerate } & & \multicolumn{2}{c}{ Stand-alone } & & \multicolumn{2}{c}{ All types } \\
\cline { 2 - 3 } \cline { 8 - 9 } Relative Size & Data & Model & & Data & Model & & Data & Model \\
\hline$<0.5$ & $3.1 \%$ & $32.2 \%$ & & $29.8 \%$ & $42.1 \%$ & & $18.3 \%$ & $38.1 \%$ \\
$0.5-1.0$ & $6.2 \%$ & $8.8 \%$ & & $30.0 \%$ & $14.1 \%$ & & $19.7 \%$ & $11.9 \%$ \\
$1.0-2.0$ & $8.4 \%$ & $6.2 \%$ & & $20.4 \%$ & $29.2 \%$ & & $15.2 \%$ & $19.8 \%$ \\
$2.0-5.0$ & $15.4 \%$ & $20.7 \%$ & & $12.1 \%$ & $8.5 \%$ & & $13.5 \%$ & $13.5 \%$ \\
$>5.0$ & $66.9 \%$ & $32.2 \%$ & & $7.7 \%$ & $6.0 \%$ & & $33.3 \%$ & $16.7 \%$ \\
All sizes & $43.3 \%$ & $40.7 \%$ & & $56.7 \%$ & $59.3 \%$ & & $100 \%$ & $100 \%$ \\
\hline \hline
\end{tabular}

Relative Size in the data is segment's value of shipments divided by industry median value of shipments. Relative Size in the model is project's production divided by the median production in the cross-section of all active projects. Statistics in the data are computed from Maksimovic and Phillips (1998), and Maksimovic and Phillips (2002) over the periods 1976-1978, 1981-1982, 1984-1988 and 1990-1991. 
The larger proportion of low size conglomerated segments can be explained by the internal capital reallocation combined with the selection of group-affiliated projects. Since inside a business group the capital is reallocated without any frictions, the most productive project will receive most of the capital and the less productive project will be operated at a smaller scale. Thus, one of the affiliated segments will generally have a larger size than the other, but this still does not explain the large quantitative difference in their size. To understand this difference quantitatively, we must look at the selection of the projects that do conglomerate. Remember from Section 5 that conglomeration is most beneficial between partners with unequal net worth and unequal managerial abilities. Because the gain from internal reallocation must be high enough to outweigh the fixed cost of conglomeration, the entrepreneurs in extremes of the distribution of net worth and abilities are most likely to conglomerate. From efficient internal capital reallocation then follows that inside groups the high-productivity entrepreneurs will operate their project on a very large scale and the low-productivity entrepreneurs will operate their project on a very small scale, leading to concentration of the mass of affiliated projects in both extremes of the size distribution. The data, on the other hand, exhibit concentration of the conglomerated firmsegments only in the large size category. This may point to existence of barriers to frictionless internal capital reallocation. As discussed in the introduction, I abstracted from the possible agency problems inside the business groups that affect the relations between headquarters and division managers. However, such agency issues may be relevant for explaining the discrepancy between the model and the data. Particularly, some frictions in the internal capital markets could limit free internal reallocation and impose minimum size requirements for each conglomerated project.

\subsection{Productivity of Conglomerates and Stand-alone Firms}

Here I relate the implications of my model to two recent papers in the empirical corporate finance literature that examine the relation between plant or firmsegment total factor productivity and diversification. Both papers (Maksimovic

and Phillips, 2002, and Schoar, 2002) measure plant-level TFP as a residual from 
the regression of the total value of plant's shipments on production inputs. Since in my model the factor shares are calibrated, I measure the project-level TFP using a standard accounting approach. Particlularly, in the model the logarithm of project $i$ 's production can be decomposed as:

$$
\ln y_{i}=\ln \theta_{i}+\nu \alpha \ln k_{i}+\nu(1-\alpha) \ln l_{i}
$$

The measured TFP of project $i$ is then equal to $\ln \theta_{i}$. In the model all firmsegments comprise only a single plant, therefore I cannot distinguish between plant-level and a firm-segment-level TFP. While my measure of TFP is directly comparable to the plant-level TFP of Schoar (2002), it may be more problematic to compare it to the firm-segment-level TFP of Maksimovic and Phillips (2002). They construct firm-segment-level TFP by averaging the plant-level TFP over the plants in this firm-segment. Although I recognize that there could be some composition effects in play while aggregating the plant-level data to the firmsegment level, as a first-order approximation I assume these effects are nil. Under this assumption it is possible to compare my project-level measure of TFP to the firm-segment-level TFP of Maksimovic and Phillips (2002).

\subsubsection{TFP Differences Unconditional on Size}

To examine the relation between average productivity and firm diversification Schoar (2002) regresses plant-level TFP on the logarithm of number of firmsegments in which the firm operates. She finds a significant positive relationship, which means that the plants in the diversified firms are on average more productive than those in stand-alone firms. ${ }^{12}$ Consistent with this evidence, I also find a positive relationship when running this regression on artificial data obtained by simulating my model. The positive relationship captures the selection of highly productive projects into conglomerates. A disproportionaly large

\footnotetext{
${ }^{12}$ In her alternative specifications, Schoar (2002) controls for the number of plants on the firm-segment and firm level. This actually makes her results even more suitable for comparison to my model since it compensates for the fact that I have only single-plant segmets. However, she does not control for the plant production size. The results in these alternative specifications are qualitatively same.
} 


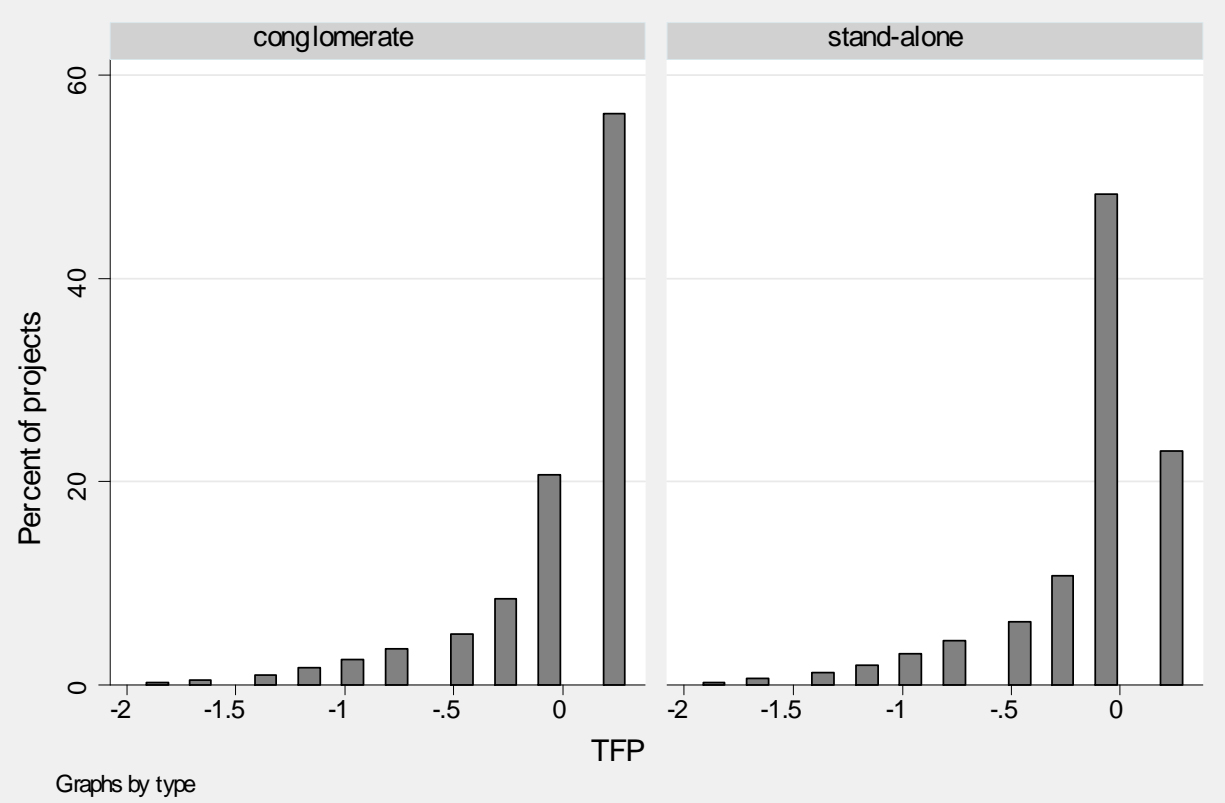

Figure IV - TFP Distribution by Firm Type

fraction of projects that end up in conglomerates have very high TFP, because the gain from internal reallocation of capital towards these projects is likely to be high. This selection can be nicely seen on Figure IV, which compares the distribution of TFP for the conglomerated and stand-alone projects.

\subsubsection{TFP Difference Conditional on Size}

Maksimovic and Phillips (2002) find that, conditional on production size, conglomerated firm-segments have on average lower TFP than the stand-alone firmsegments. This might seem in contradiction with the finding of Schoar (2002) and the results of the previous section. However, from the statistics reported in Maksimovic and Phillips (2002) one can infer, with simple calculations, the unconditional means of TFP for the segments in conglomerates and single-segment firms. Interestingly, one then finds that unconditial on size, the firm-segments in conglomerates are more productive than the stand-alone firm-segments. Therefore, the results of the two papers are not incompatible. The model allows to understand some of the effects that can be in play.

If we run a regression of TFP on a conglomeration dummy and we control for 
the project's relative production size in the artificial data, we find, in line with Maksimovic and Phillips (2002), a negative relation between TFP and conglomeration. Examining more in detail the mechanisms of the model, we discover that the conglomerates are on average less productive when controlling for size because they allocate capital from less productive projects to more productive ones, eliminating the capital-productivity mismatch. Figure $\mathrm{V}$ visualizes this effect. It gives the distribution of TFP for projects of relative production size between 0.1 and 0.15 (left panel), and projects of relative production size between 1.35 and 1.4 (right panel). For smaller production sizes, there is less high-productivity projects constrained to operate at this size among conglomerated firm-segments than among stand-alone firms. Consequently, the average TFP in these size categories is lower among conglomerated firm-segments. For very large sizes the composition effect goes in the opposite direction. However, it comes out that in the regression the former effect dominates. This is because TFP is bounded from above and all projects larger than a certain thereshold have the highest TFP whether they are in conglomerates or not.
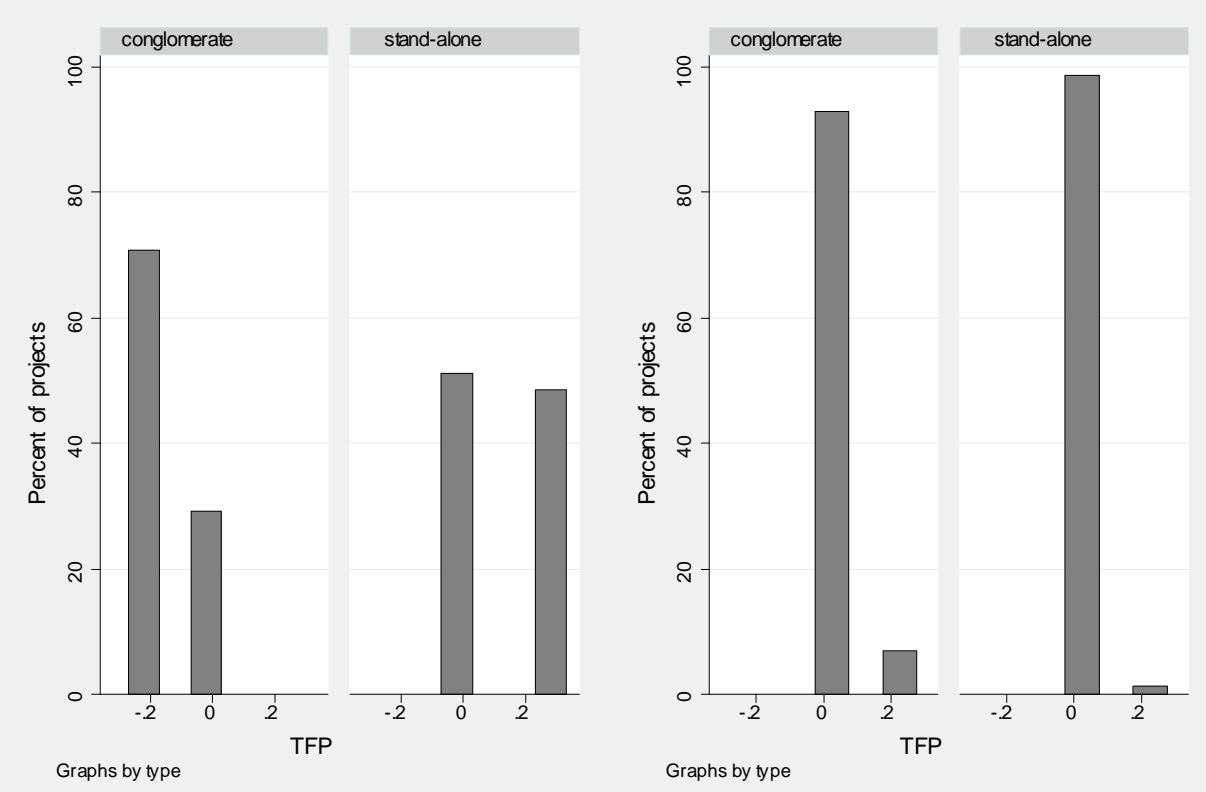

Figure V - TFP Distribution Conditional on Production Size (low size in the left panel, high size in the right panel) 
Maksimovic and Phillips (2002), and some other studies that cite their paper, broadly interpret lower productivity of conglomerates conditional on size as evidence of their low performance compared to the specialized firms. However, my results indicate that one should be careful with making conclusions on performance of conglomerates based on this finding, especially in presence of frictions in the external capital market. When conditionning on size, the negative relation between TFP and conglomeration may actually stem from reallocation of capital towards highly productive projects inside conglomerates, which should have a positive impact on performance.

Another way to see the implications of internal reallocation on size and productivity is to look at average production size conditional on productivity. Since in the model TFP is discretized, we can easily plot the average relative production size and TFP for conglomerated firm-segments and stand-alone firms, what is done in Figure VI. ${ }^{13}$ We see that, except in the highest productivity class, the average size of conglomerated firm-segments is lower. This suggests that conglomerates channel the capital more aggressively from low to the highest productivity projects than the external credit market.

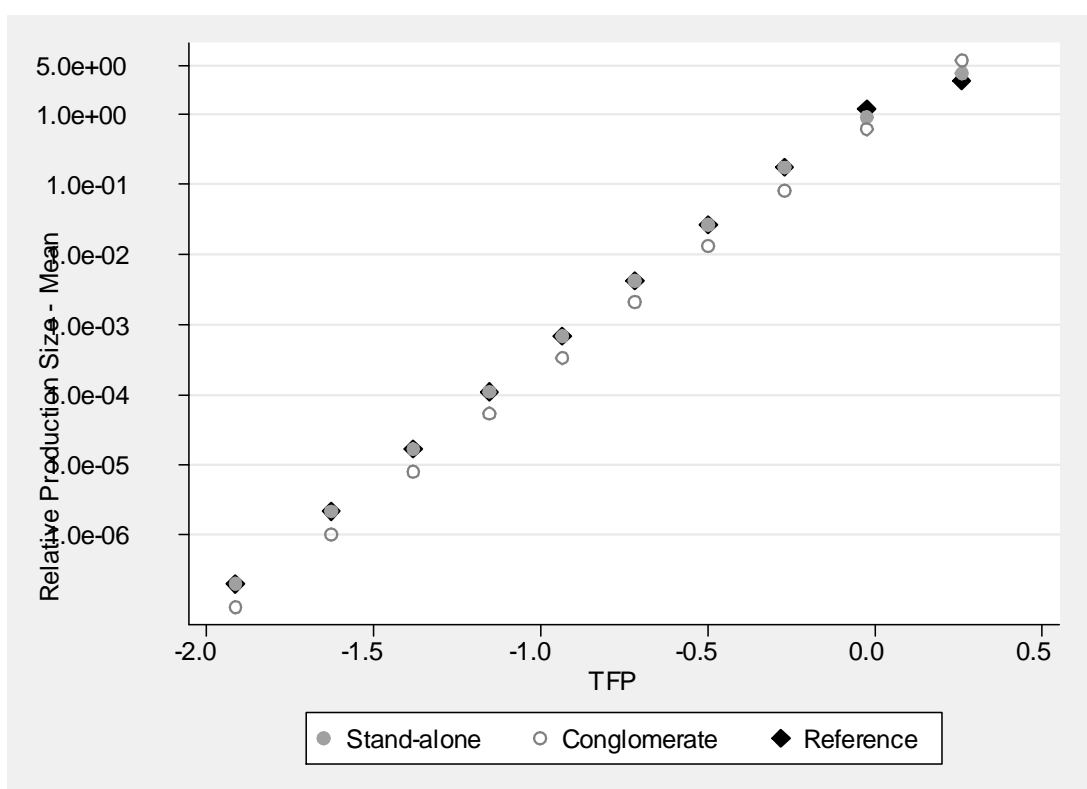

Figure VI - Average Production Size and Productivity

\footnotetext{
${ }^{13}$ In Figure VI y-axis is scaled logarithmically.
} 
One may be concerned with the fact that, due to selection, the underlying distribution of internal funds is not the same for stand-alone and conglomerated projects. To adress this issue, I plot the hypothetical average size of projects that select into conglomerates if they were forced to remain stand-alone. In that situation they would be constrained to use only the amount of capital that they were able to raise with their own internal funds. I call these averages "Reference" points, and they are depicted as black dimonds in Figure IV. The Reference points closely follow the average size of stand-alone firms except for the two most productive categories, where they actually emphasize even more the internal reallocation towards the highest productivity projects. Clearly, this confirms that conglomerates allocate capital more efficiently than stand-alone firms on average. Their average performance, measured by profit creation or capital allocation efficiency, should therefore be higher than that of single-segment firms in evirnonments with frictions in external markets. This finding is consistent with Santalo and Beccera (2008), who find a conglomerate premium in industries in which information that is not verifiable by company outsiders is important, and a conglomerate discount in industries in which such "inside" information is not important.

\section{Quantitative Experiments}

\subsection{Credit Frictions and the Degree of Conglomeration}

This section examines how the degree of conglomeration in the economy changes with the severity of borrowing constraints. The implications of the model are then contrasted with the data. Specifically, I ask whether cross-country differences in the degree of conglomeration tend to be associated with measures of investor protection (my proxy for credit constraints) in the way predicted by the model.

Figure VII depicts some comparative statics with respect to the enforcement parameter $\eta$. Lower enforcement, or, equivalently, more severe credit constraints, leads to higher levels of entrepreneurship, higher degree of conglomeration, lower prices, lower average output per firm-segment, and lower output per capita. ${ }^{14}$ The proportion of entrepreneurs in the economy is higher with tighter credit

\footnotetext{
${ }^{14}$ Output is net of fixed costs of conglomeration.
} 

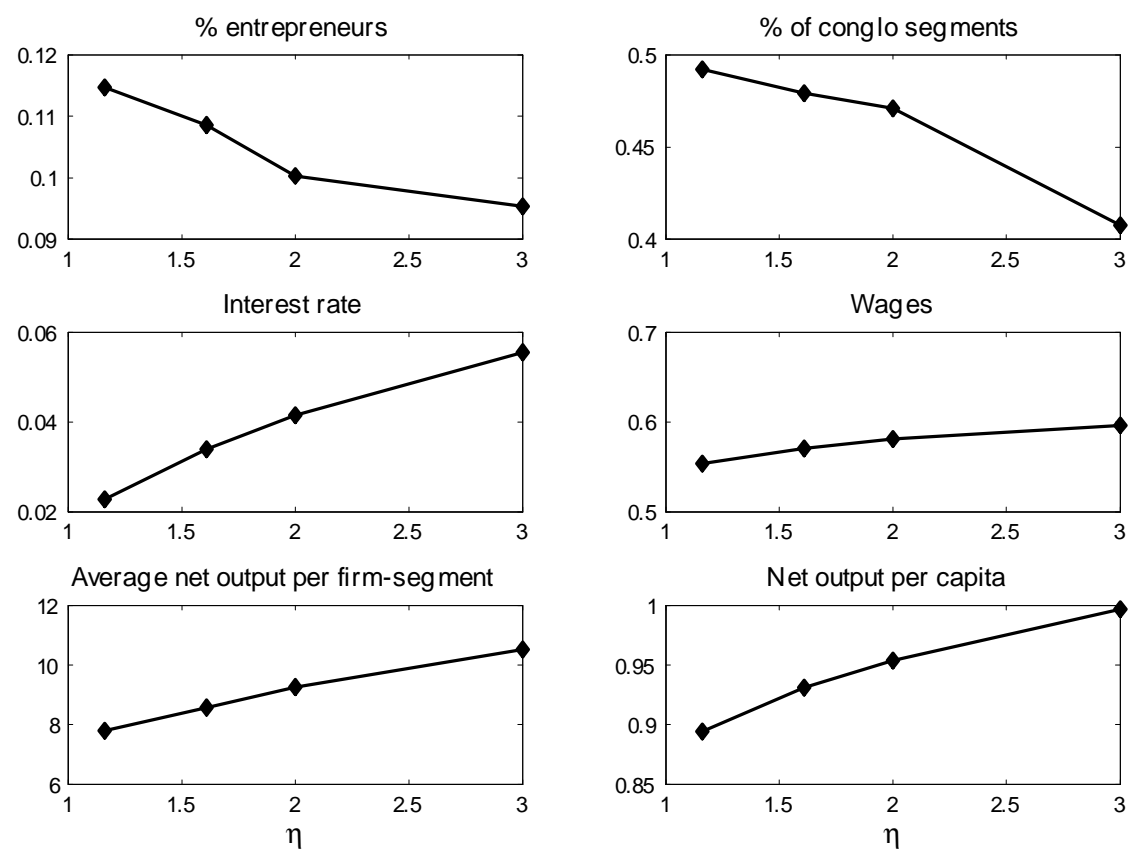

Figure VII - Comparative Statics

constraints because lower wages and interest rates make the entrepreneurship profitable (compared to working for wage) for types with lower managerial abilities. Notice that this mechanism endogenously reproduces stylized fact number five - in economies with lower aggregate output there is a higher number of active entrepreneurs operating lower scale projects.

Due to lack of quality data on conglomeration and difficulty to measure credit constraints in a broad cross-section of countries, it is hard to evaluate whether the model is able to generate differences in degree of conglomeration consistent with the data. However, Figure VI aims to give an idea on this issue. It plots the degree of conglomeration and an investor protection index normalized by its the level in the US. The real-life data points are labeled by three letter country codes. The connected diamonds correspond to model equilibria in which the enforcement parameter, normalized by its level in the benchmark calibration, is equal to the relative investor protection on the x-axis. The abcissas 


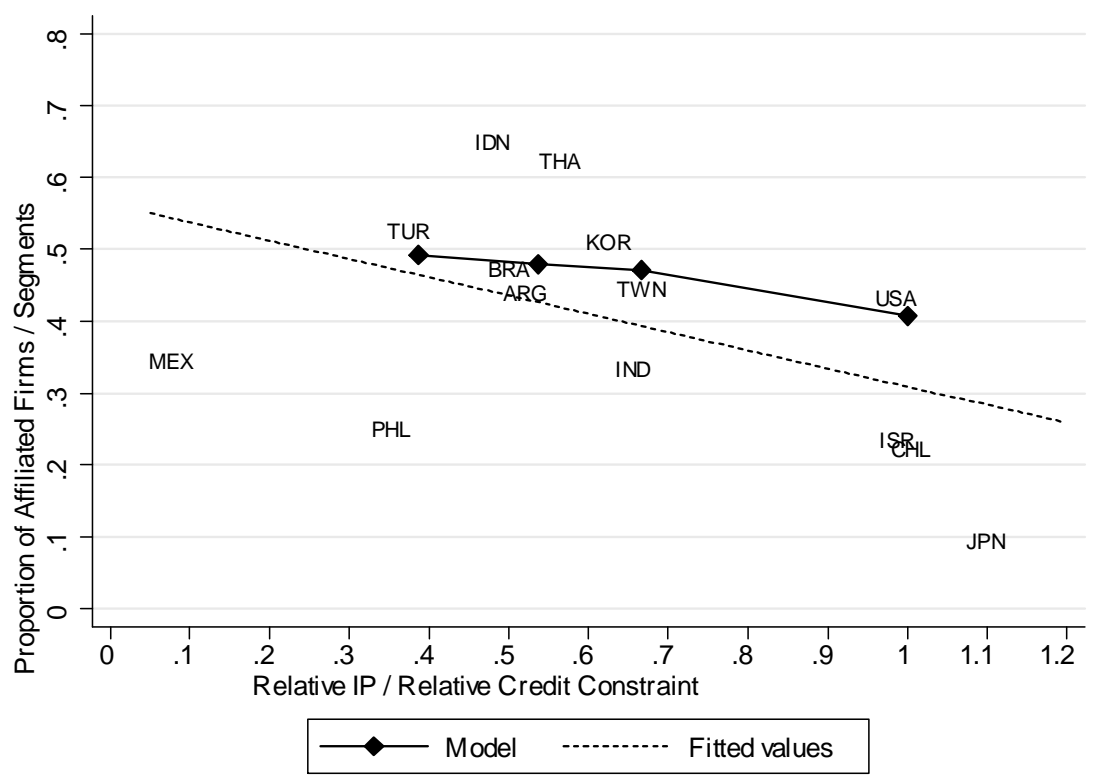

Figure VIII - Conglomeration and Credit Constraints

for the simulation points were selected to be equal to quintiles of the distribution of relative investor protection. The model gets quite well the average degree of conglomeration of countries in the second, and third quintile of the distribution. The evaluation out of this range is difficult due to low number of data points.

In any case, the reader should take all comparisons based on Figure VIII only as a broad illustration. More precise conclusions are problematic since investor protection indices are ordinal variables that are not suitable for quantitative comparisons, whereas the enforcement parameter in the model has a precise quantitative meaning and implications.

\subsection{Restrictions on Conglomeration}

In this section I look at effects of policies that raise the cost of conglomeration. In my model conglomeration has two opposing effects on macroeconomic aggregates. First, for any given prices, the internal capital markets reduce the misallocation of capital over the productive projects. This allows highly productive entrepreneurs to operate their projects at sizes closer to their unconstrained levels and raises the level of entrepreneurship. Second, via general equilibrium restrictions, 
conglomeration implies higher prices of production factors, which tends to reduce production size of all projects and the level of entrepreneurship.

As mentioned in the introduction, my paper is not the first to study these effects. Indeed, Almeida and Wolfenzon (2006) speculate that the negative general equilibrium effect may be dominant in environments with intermediate level of investor protection. This would have important implications in terms of policies restricting conglomeration such as merger and acquisition regulation. However, no work in my best knowledge attempts to measure these effects quantitatively. To do such quantitative comparisons in my model, I consider following three scenarios. A "No Groups" stationary equilibrium in which conglomeration is prohibitely costly and no business groups emerge, a "Groups Partial" perspective in which prices are held constant on their level in the "No Groups" scenario, but in which the cost of conglomeration is as in the benchmark calibration, and a "Group Benchmark" stationary equilibrium that corresponds to the benchmark calibration. The Groups Partial is an off-equilibrium scenario in which agents optimize, but they expect prices and the joint type distribution to be as in the stationary equilibrium without groups. Although in this situation markets are not cleared and the resulting distributions of wealth and production size are not invariant, I believe it can serve, as a rough approximation, for evaluating the direct effect of conglomeration separately from the general equilibrium effect.

Refer to Table V. Comparing the Groups Partial scenario to the No Groups scenario gives us some information on the direct effects of conglomeration. If the prices stayed at the No Groups level, possibility of forming groups would raise entrepreneurship by $37 \%$. A possible match with a suitable partner makes entrepreneurship profitable for many agents, who would choose to work if they were constrained to operate their project alone. The rise in entrepreneurship and the possibility to relax credit constraints and reallocate capital internally boosts the aggregate demand for capital by $110 \%$, and the aggregate output by $189 \%$. The average proportion of external financing decreases because internal capital reallocation allows to cimcurvent the external credit markets to some extent. The agents also tend to save more on average (increase by $6.5 \%$ in the saving rate) because of improved the prospects for investing the savings efficiently through a business group partnership. 
Table V - Aggregate Effects of Conglomeration

\begin{tabular}{|c|c|c|c|}
\hline Statistic & $\begin{array}{c}\text { No } \\
\text { Groups }\end{array}$ & $\begin{array}{l}\text { Groups } \\
\text { Partial }\end{array}$ & $\begin{array}{c}\text { Groups } \\
\text { Benchmark }\end{array}$ \\
\hline Cost of conglomeration & 1000 & 0.5 & 0.5 \\
\hline Interest rate & $3.67 \%$ & $3.67 \%$ & $5.56 \%$ \\
\hline Wage rate & 0.56 & 0.56 & 0.60 \\
\hline Proportion entrepreneurs & 0.08 & 0.19 & 0.10 \\
\hline Proportion conglomerate firm-segments & 0.00 & 0.57 & 0.41 \\
\hline Aggregate demand for capital & 1.83 & 5.68 & 1.93 \\
\hline Net output per capita & 0.95 & 2.70 & 1.00 \\
\hline Net output per capital unit & 0.52 & 0.48 & 0.52 \\
\hline Net output per efficiency unit of labor & 1.02 & 3.19 & 1.07 \\
\hline Average proportion of external financing & 0.71 & 0.62 & 0.52 \\
\hline Average saving rate & 0.46 & 0.49 & 0.48 \\
\hline
\end{tabular}

No Groups refers to stationary equilibrium with prohibitive cost of conglomeration, Groups Partial refers to off-equilibrium scenario in which prices are held constant at the No Groups level, Groups Benchmark refers to the stationary equilibrium under the benchmark calibration. Net output is output minus fixed costs of conglomeration.

Off course, the numbers cited above look quite spectacular, but I have to remind the reader that they correspond to an off-equilibrium situation and illustrate only one part of the story. The second part are the general equilibrium effects of conglomeration, which can be illustrated by comparing the Groups Benchmark scenario to the Groups Partial scenario. In the former prices adjust so that all markets clear and the joint distribution of wealth and abilities are stationary. Higher prices of production factors (interest rate and wages go up by $51 \%$ and $7 \%$, respectively) make entrepreneurship less profitable and put it back to the level of 0.1 , a decrease by $47 \%$ comared to the Groups Partial scenario. The same apply to aggregate demand for capital and aggregate output. Relative to the Groups Partial scenario, they are, respectively, by $66 \%$ and $67 \%$ lower. The average proportion of external financing continues to decrease by $16 \%$, the reason being the higher price of external finance. 
Put toghether, the direct and the general equilibrium effects compensate each other resulting in a much smaller, but still significant, variation across the stationary equilibria with and without groups. The equilibrium with business groups features higher level of entrepreneurship by $25 \%$, higher levels of capital accumulation and aggregate output (by $5.4 \%$ and $6.3 \%$, respectively), and a lower level of external financing than the equilibrium without conglomeration. This suggests that internal capital markets play quite important role in allocating ressources to their more productive use and that this beneficial effect outweights the negative general equilibrium effect. This result is in line with a recent study of broader size-restricting policies by Guner, Ventura, and Xu (2008). My analysis complements their work by focusing on a particular type of these policies that restrict conglomeration. However, an important caveat applies since my analysis assumes away any ties between governments and business groups. In several countries large diversified groups tend to be closely connected to the politicians, which may sometimes lead to inefficient outcomes such as corruption, oversubsidizing of groups, or concentration of market power through state-granted monopoly rights.

\section{Concluding Remarks}

This paper contributes to the literature studying conglomerates and business groups. I consider the role of conglomeration in an economy with financial frictions. In my model conglomeration arises endogenously as a way for firms to partially avoid external credit market imperfections, and to reallocate the available capital across affiliated projects more efficiently. The quantitative analysis shows that this view of conglomeration is consistent with several observed stylized facts on how production is organized across firms, on productivity differences between conglomerates and stand-alone firms, and on cross-country differences in degree of conglomeration.

In the last section I broadly invoke some policy-related implications of my theory. The model suggests that conglomeration may have a positive effect on economic development through improving the allocation of capital to productive projects. Therefore, regulations restricting conglomeration may be potentially harmful. 
I can think of at least three important points where my analysis may be improved. First, I have abstracted from potentially important agency problems that may arise inside business groups between the headquarters and divisional managers. These problems are likely to limit the extent to which the headquarters may reallocate the capital across projects. Considering them explicitely may help to better reproduce the marked concentration of conglomerated firm-segments in the large size categories. It would also allow us to better understand the inner working of conglomerates. Such an extension, however, would require thinking more deeply about detailed ownership and control structure of conglomerated firms and business groups, which varies considerably even within a given country.

Second, I have also abstracted from business groups dynamics. Allowing for long-lived business groups may help understand the observed persistence in group affiliation and the long-term interactions among the affiliated firms.

Finally, I have not considered the market and political power that is often concentrated in the hands of large business groups. While the market power considerations could help better understand market structure and innovation and pricing behavior of firms, a political economy extension could shed some light on emergence of subsidy policies, barriers to entry, or barriers to financial development. 


\section{Appendix - Numerical Algorithm}

I solve the model using value function iteration. The algorithm was programmed in Fortran 90. The main step finds the interest rate, the wage rate, and the correspoding invariant distribution over individual states such that the capital market and the labor market clear. The invariant distribution is stored as a long $N=3$ million sample of triplets $\left(\zeta_{n}, \theta_{n}, a_{n}\right)$. The algorithm proceeds as follows.

1. Guess the prices $r^{p}, w^{p}$ and the invariant distribution $\left(\left\{\zeta_{n}, \theta_{n}, a_{n}\right\}_{n=1}^{N}\right)^{p}$.

2. Given the guesses, solve the individuals' problem. The Bellman equation (1) is solved on a finite number of states. Particularly, the end-of-period assets $\omega$ and the net worth at the beginning of period $a$ are discretized into grids. To evaluate the value functions on the points outside this grid, I use a shape-preserving spline interpolation. To compute the expected value of entrepreneurship I use a selection of entrepreneurs from the guessed invariant distribution as a sample of business partners. The expectation is approximated by a Monte-Carlo integral over 1000 points. Once convergence of value functions is achieved, I recompute the saving decision rules on a much finer grid of the end-of-period assets.

3. Obtain the updated invariant distribution over individual states $\left(\left\{\zeta_{n}, \theta_{n}, a_{n}\right\}_{n=1}^{N}\right)^{p+1}$ by using the system's transition function to simulate a long $N=3$ million time-series for an individual agent. To obtain conglomeration decisions, I use a selection of entrepreneurs from the guessed invariant distribution as a sample of business partners. To update saving decision rules I use piecewise linear interpolation.

4. Check capital and labor market clearing conditions. If markets do not clear, choose new interest rate $r^{p+1}$ and wage rate $w^{p+1}$ accordingly. The algorithm terminates when both excess demands are lower than $10^{-3}$. 


\section{References}

[1] Almeida, Heitor, and Daniel Wolfenzon. 2006. "Should Business Groups Be Dismantled? The Equilibrium Cost of Efficient Internal Capital Markets.", Journal of Financial Economics, 79, 99-144.

[2] Almeida, Heitor, and Daniel Wolfenzon. 2006b. "A Theory of Pyramidal Ownership and Family Business Groups.", Journal of Finance, 61, 26372680 .

[3] Amaral, Pedro, and Erwan Quintin. 2007. "Financial Intermediation and Economic Development: A Quantitative Assesment.", working paper, Federal Reserve Bank of Dallas, February 2007.

[4] Bohacek, Radim. 2006. "Financial Constraints and Entrepreneurial Investment.", Journal of Monetary Economics, 53, 2195-2212.

[5] Buera, Francisco J., and Yongseok Shin. 2007. "Financial Frictions and the Persistence of History: A Quantitative Exploration.", working paper, Northwestern University, September 2007.

[6] Burnside, Craig A. 1996. "Production Function Regressions, Returns to Scale, and Externalities.", Journal of Monetary Economics, 37, 177-201.

[7] Cagetti, Marco, and Mariacristina De Nardi. 2006. "Entrepreneurship, Frictions, and Wealth.", Journal of Political Economy, 114, 835-870.

[8] Classens, Stijn, Simeon Djankov, and Larry H. P. Lang. 2000. "The Separation of Ownership and Control in East Asian Corporations.", Journal of Financial Economics, 58, 81-112.

[9] Classens, Stijn, Joseph P. H. Fan, and Larry H. P. Lang. 2006. "The Benefits and Costs of Group Affiliation: Evidence from East Asia.", Emerging Markets Review, 7, 1-26.

[10] Faccio, Mara, and Larry H. P. Lang. 2002. "The Ultimate Ownership of Western European Corporations.", Journal of Financial Economics, 65, 365395 .

[11] Gollin, Douglas. 2008. "Nobody's Business but My Own: Self-employment and Small Entreprise in Economic Develompent.", Journal of Monetary Economics, 55, 219-233.

[12] Gomes, Joao, Jeremy Greenwood, and Sergio Rebelo. 2001. "Equilibrium Unemployment.", Journal of Monetary Economics, 48, 109-152. 
[13] Gomes, Joao, and Dmitry Livdan. 2004. "Optimal Diversification: Reconciling Theory and Evidence.", Journal of Finance, 59, 507-535.

[14] Guner, Nezih, Gustavo Ventura, and Yi Xu. 2008. "Macroeconomic Implications of Size-dependent Policies.", Review of Economic Dynamics, 11, 721-744.

[15] Hoshi, Takeo, Anil Kashyap, and David Scharfstein. 1991. "Corporate Structure, Liquidity, and Investment: Evidence from Japanese Industrial Groups.", Quarterly Journal of Economics, 106, 33-60.

[16] Hubbard, Glenn, and Darius Palia. 1999. "A Reexamination of the Conglomerate Merger Wave in the 1960s: An Internal Capital Markets View.", Journal of Finance, 54, 1131-1152.

[17] Huggett, Marc. 1997. "The One-sector Growth Model with Idiosyncratic Shocks: Steady States and Dynamics.", Journal of Monetary Economics, 39, 385-403.

[18] Kaufmann, Daniel, Aart Kraay, and Massimo Mastruzzi. 2006. "Governance Matters V: Aggregate and Individual Governance Indicators fo 1996 - 2005.", World Bank Policy Research Working Paper No. 4012.

[19] Khanna, Tarun, and Krishna Palepu. 1997. "Why Focused Strategies May Be Wrong for Emerging Markets.", Harvard Business Review, 75, 41-51.

[20] Khanna, Tarun, and Krishna Palepu. 2000. "Is Group Affiliation Profitable in Emerging Markets? An Analysis of Diversified Indian Business Groups.", Journal of Finance, 55, 867-891.

[21] Khanna, Tarun, and Yishay Yafeh. 2005. "Business Groups and Risk Sharing around the World.", Journal of Business, 78, 301-340.

[22] Khanna, Tarun, and Yishay Yafeh. 2007. "Business Groups in Emerging Markets: Paragons or Parasites?", Journal of Economic Literature, 45, 331372 .

[23] La Porta, Raphael, Florencio Lopez-de-Silanez, Andrei Shleifer, and Robert W. Vishny. 1998. "Law and Finance.", Journal of Political Economy, 106, 1113-1155.

[24] Lang, Larry, and Rene Stulz. 1994. "Tobin's q, Corporate Diversification, and Firm Perfomance.", Journal of Political Economy, 102, 1248-1280. 
[25] Lucas, Robert E. Jr. 1978. "On the Size Distribution of Business Firms.", Bell Journal of Economics, 9, 508-523.

[26] Maksimovic, Vojislav, and Gordon Phillips. 2002. "Do Conglomerate Firms Allocate Resources Inefficiently across Industries? Theory and Evidence.", Journal of Finance, 57, 721-767.

[27] Maksimovic, Vojislav, and Gordon Phillips. 1998. "Optimal Firm Size and the Growth of Conglomerate and Single-Industry Firms.", working paper 98-14, Center for Economic Studies, U.S. Census Bureau.

[28] Perotti, Enrico, C., and Stanislav Gelfer. 2001. "Red Barons or Robber Barons? Governance and Investment in Russian Financial-industrial Groups.", European Economic Review, 45, 1601-1617.

[29] Quadrini, Vincenzo. 2000. "Entrepreneurship, Saving, and Social Mobility.", Review of Economic Dynamics, 3, 1-40.

[30] Rajan, Raghuram G., Henri Servaes, and Luigi Zingales. 2000. "The Cost of Diversity: Diversification Discount and Inefficient Investment.", Journal of Finance, 55, 35-80.

[31] Santalo, Juan, and Manuel Becerra. 2008. "Competition from Specialized Firms and the Diversification - Performance Linkage.", Journal of Finance, $63,851-883$.

[32] Scharfstein, David S., and Jeremy C. Stein. 2000. "The Dark Side of Internal Capital Markets: Divisional Rent-Seeking and Inefficient Investment.", Journal of Finance, 55, 2537-2564.

[33] Schoar, Antoinette. 2002. "Effects of Corporate Diversification on Productivity.", Journal of Finance, 57, 2379-2403.

[34] Shin, Hyun-Han, and Young S. Park. 1999. "Financing Constraints and Internal Capital Markets: Evidence from Korean 'Chaebols'.", Journal of Corporate Finance, 5, 169-191.

[35] Stein, Jeremy C. 1997. "Internal Capital Markets and the Competition for Corporate Resources.", Journal of Finance, 52, 111-133.

[36] Stein, Jeremy C. 2003. "Agency, Information and Corporate Investment.", Handbook of the Economics of Finance, volume 1, 111-165. 
[37] Tauchen, George, and Robert Hussey. 1991. "Quadrature-Based Methods for Obtaining Approximate Solutions to Nonlinear Asset Pricing Models.", Econometrica, 59, 371-396.

[38] Tybout, James, R. 2000. "Manufacturing Firms in Developing Countries: How Well They Do, and Why?", Journal of Economic Literature, 38, 11-44.

[39] Vereshchagina, Galina, and Hugo A. Hopenhayn. 2006. "Risk Taking by Entrepreneurs.", working paper, University of Iowa.

[40] Villalonga, Belén. 2004. "Diversification Discount or Premium? New Evidence from BITS Establishment-level Data.", Journal of Finance, 59, 479505 . 